\title{
Effects of different sources of carbohydrates on intake, digestibility, chewing, and performance of Holstein dairy cows
}

\author{
Simin Poorkasegaran ${ }^{1}$ and Asadollah Teimouri Yansari ${ }^{1,2^{*}}$
}

\begin{abstract}
To investigate the effects of different sources of carbohydrates on intake, digestibility, chewing, and performance, nine lactating Holstein dairy cows (day in milk $=100 \pm 21 \mathrm{~d}$; body weight $=645.7 \pm 26.5 \mathrm{~kg}$ ) were allotted to a $3 \times 3$ Latin square design at three $23-\mathrm{d}$ periods. The three treatments included $34.91 \%$ (B), 18.87\% (BC), and 18.86\% (BB) barley that in treatment $B$ was partially replaced with only corn or corn plus beet pulp in treatments $B C$ and $B B$, respectively. The concentration of starch and neutral detergent soluble carbohydrate varied (22.2, 20.2, and 14.5; $13.6,15.9$, and $20.1 \%$ of $D M$ in treatments $B, B C$, and BB, respectively). Cows in treatment BB showed a higher DMI and improved digestibility of $\mathrm{DM}, \mathrm{NDF}$, and $\mathrm{EE}$ compared with treatments $\mathrm{B}$ or $\mathrm{BC}$. Ruminal $\mathrm{pH}$ was higher in cows fed on BB (6.83) compared with those that received B or BC treatments (6.62 and 6.73, respectively). A lower proportion of propionate accompanied the higher $\mathrm{pH}$ in the $\mathrm{BB}$ group; however, a greater proportion of acetate and acetate: propionate ratio was observed compared with cows fed either on the B or BC diet. Moreover, cows fed on the BB diet showed the lowest ruminal passage rate and longest ruminal and total retention time. Eating time did not differ among treatments, rumination time was greater among cows fed on the BB diet compared with the others, whereas total chewing activity was greater than those fed on BC, but similar to those fed on $\mathrm{B}$. The treatments showed no effect on milk yield. Partially replacing barley with corn or beet pulp resulted in an increase in milk fat and a lower protein concentration. Changing dietary NFC with that of a different degradability thus altered intake, chewing activity, ruminal environment, retention time or passage rate, and lactation performance. The results of this study showed that beet pulp with a higher NDF and a detergent-soluble carbohydrate or pectin established a more consistent ruminal mat than barley and corn, thus resulting in higher mean retention time and chewing activity, whereas no changes in 3.5\% FCM and milk fat were observed.
\end{abstract}

Keywords: Chewing activity, Dairy cow, Detergent-soluble carbohydrate, Fiber, Neutral detergent fiber, Physically effective fiber, Ruminal characteristics

\section{Background}

Three components affect the balance of carbohydrates in the diets of lactating dairy cattle. The first two are the nature of the NDF and the nature of non-fiber carbohydrates (NFC), and the third component is one of the following: NDF content, NFC content, or NDF:NFC ratio [1-3]. Carbohydrates consisting of NDF and NFC fractions make up $65 \%-75 \%$ of rations. However, issues have

\footnotetext{
* Correspondence: astymori@yahoo.com

'Department of Animal Science, Animal Science and Aquaculture Faculty, Sari Agricultural and Natural Resource University, Sari, Mazandaran, Iran ${ }^{2}$ Department of Animal Science, Educational Center of Tajan, GhaemShahar, Mazandaran, Iran
}

been associated with the use of an NDF because this component ranges from $27 \%$ to $37 \%$ in dietary DM, whereas NFC content ranges from $45 \%$ to $35 \%[3,4]$. The NFC has been represented as a single value for feeds or diets, but the type of carbohydrates in this fraction largely varies. For example, the NFC in corn grain is mostly starch $(65 \%-70 \%$ of DM), beet and citrus pulp provides sugar $(12 \%-40 \%$ of DM) and neutral detergentsoluble carbohydrate (NDSC) $(25 \%-44 \%$ of DM), and sugar (mono- and oligosaccharides) predominates in molasses [5]. In addition, some of the variation in the results of the effect of the type and amount of NFC on high-producing lactating cows may be related to: 1) the

\section{Biomed Central}


effects of rapidly degradable starch on ruminal digestion of fiber; 2) the level to which NFC replaces fiber in the ration; 3) the site of starch digestion; 4) the level of DMI and the physiological state of the animal; and 5) the conservation and processing methods of NFC sources used to alter the rate and the extent of NFC digestion [4-6]. However, the optimal concentration of NFC in dairy cow diets has not been well defined. The lack of clear recommendations may be at least due to the wide compositional and nutritional variation in the sources of NFC, the kinetics of ruminal digestion, and the yields of metabolizable nutrients [4]. Therefore, improving the understanding of the digestion and metabolism of various NFC types that are fed to dairy cattle can improve animal performance and profitability while maintaining health.

The physically effective NDF (peNDF) incorporates information on particle length, NDF content of the diet, and impact of replacing forage fiber with NFC based on the use of small particles of byproducts and measuring the animal's chewing activity $[7,8]$. However, this concept does not account for different sources of NFC or differences in fermentability among various feeds. The nature of NFC differs among feeds and diets. In evaluating the effectiveness of the NDF approach, the effect of removing or adding NFC has been entirely attributed to NDF $[1,2,9]$. Based on this simple assumption, the effectiveness of NDF from all sources is thus based on the replacement of NFC. Therefore, understanding the nutritional value of each NFC type may aid in the use of available feeds, including byproducts, to efficiently formulate dairy cow diets that would enhance production and health. However, extensive information on the optimal level of starch and digestible fiber in rations for dairy cows is warranted to facilitate in the design of strategies to prevent ruminal acidosis and the efficient conversion of energy into milk. The objective of this trial was to compare the effects of three different carbohydrate sources, namely barely, corn, and beet pulp (BP), on stimulating intake, digestibility, chewing activity, ruminal characteristics, and early lactation in Holstein dairy cows.

\section{Materials and methods}

\section{Animals and diets}

The experiment was conducted at the Dairy Farm of the Agricultural Education and Research Centre of Jehad-eKeshavarzi, Sari, Iran. Nine multiparous mid-lactation Holstein dairy cows $(\mathrm{BW}=645.7 \pm 26.5 \mathrm{~kg}$; DIM $=100 \pm$ $21 \mathrm{~d}$ ) were subjected to a $3 \times 3$ Latin square design. The experiment consisted of three 23-d periods (adaptation, $14 \mathrm{~d}$; sample collection, $7 \mathrm{~d}$; and measurement of chewing activity, $2 \mathrm{~d})$. The three treatments containing $34.91 \%(B), 18.87 \%(B C)$, and $18.86 \%$ (BB) barley as DM were used. The barley in treatment B was partially replaced with only corn or corn plus beet pulp in treatments $\mathrm{BC}$ and $\mathrm{BB}$, respectively (Table 1 ). Barley grain, corn grain, and $\mathrm{BP}$ were prepared by milling normal $\mathrm{BP}$ using a 2-mm screen pore size miller. Diets were similar in chemical (16\% CP and $6.65 \mathrm{MJ} / \mathrm{kg}$ of NEL) and physical (geometric mean and peNDF) characteristics

Table 1 Ingredients and chemical composition of three total mixed rations containing three different sources of non-fiber carbohydrates

\begin{tabular}{lccc}
\hline \multirow{2}{*}{ Item } & \multicolumn{3}{c}{ Treatments $^{\mathbf{1}}$} \\
\cline { 2 - 4 } Ingredients, \% of DM ${ }^{2}$ & & BC & BB \\
Alfalfa hay & 23.41 & 23.69 & 23.57 \\
Wheat straw & 15.53 & 15.84 & 15.8 \\
Barley grain & 34.91 & 18.87 & 18.86 \\
Corn grain & $\ldots$ & 15.89 & $\ldots$ \\
Beet pulp & $\ldots$ & $\ldots$ & 15.89 \\
Cotton seed meal & 11.19 & 8.88 & 8.90 \\
Soybean meal & 3.01 & 2.99 & 3.01 \\
Wheat bran & 8.01 & 9.68 & 9.69 \\
Sunflower meal & 2.69 & 2.99 & 3.01 \\
Calcium carbonate & 0.43 & 0.4 & 0.5 \\
Calcium phosphate & 0.25 & 0.20 & 0.20 \\
Salt & 0.10 & 0.10 & 0.10 \\
Vitamin supplement & \\
& 0.25 & 0.25 & 0.25 \\
Urea & 0.22 & 0.22 & 0.22
\end{tabular}

Chemical compositions, \% of DM

\begin{tabular}{|c|c|c|c|c|c|}
\hline CP & 16.2 & 15.9 & 15.9 & 0.232 & 0.321 \\
\hline NDF & 36.2 & 36.9 & 37.7 & 0.864 & 0.079 \\
\hline ADF & 23.1 & 22.6 & 24.6 & 0.541 & 0.092 \\
\hline NFC & 38.9 & 38.9 & 37.9 & 0.682 & 0.061 \\
\hline Starch & $22.2^{\mathrm{a}}$ & $20.2^{\mathrm{a}}$ & $14.5^{\mathrm{b}}$ & 0.792 & 0.001 \\
\hline Sugar & 3.1 & 2.8 & 3.3 & 0.432 & 0.213 \\
\hline $\mathrm{NDSC}^{4}$ & $13.6^{c}$ & $15.9^{\mathrm{b}}$ & $20.1^{\mathrm{a}}$ & 0.232 & 0.001 \\
\hline EE & 2.3 & 2.4 & 2.4 & 0.219 & 0.212 \\
\hline Ash & 6.4 & 5.9 & 6.1 & 0.672 & 0.431 \\
\hline $\mathrm{NEI}^{5}, \mathrm{Mcal} / \mathrm{kg}$ of DM & 1.58 & 1.59 & 1.58 & 0.232 & 0.452 \\
\hline
\end{tabular}

a, b, c Means within a row with different subscripts differ $(P<0.05)$.

${ }^{1}$ Treatments were diets containing barley + basal diet (B), barley and corn + basal diet (BC), and barley and beet pulp + basal diet (BB).

${ }^{2}$ Alfalfa, wheat straw, barley grain, corn, beet pulp, cotton seed meal, soy bean meal, wheat bran, and sun flower meal (DM basis) were chemically composed of $89.1 \%, 50.9 \%, 18.7 \%$, and $15.3 \% ; 91.2,75.2,10.4$, and 3.4; 93.2, 22.1, 55.4, and $10.5 ; 96.7,11.0,78.3$, and $8.5 ; 93.4,44.4,41.0$, and 9.0; 90.7, 45.2, 16.3, and 27.3; 90.3, 17.8, 24.7, and 42.5; 90.3, 52.3, 24.4, and 16.5; and 92.0, 55.7, 17.3, and 16.1 for OM, NDF, NFC, and CP, respectively.

${ }^{3}$ Contained $40 \% \mathrm{NaCl}, 25 \%$ Dyna mate, $10 \% \mathrm{~K}, 7 \% \mathrm{Mg}, 12 \% \mathrm{~S}, 1,000 \mathrm{mg} \mathrm{Fe} / \mathrm{kg}$, $2 \% \mathrm{ZnSO}_{4} \cdot \mathrm{H}_{2} \mathrm{O}, 2 \% \mathrm{MnSO}_{4} \cdot 4 \mathrm{H}_{2} \mathrm{O}, 0.01 \% \mathrm{CoSO}_{4} \cdot 6 \mathrm{H}_{2} \mathrm{O}, 0.009 \% \mathrm{Na}_{2} \mathrm{SeO}_{3}, 0.012 \%$ ethylenediamine dihydroiodide, $0.8 \% \mathrm{CuSO}_{4} .5 \mathrm{H}_{2} \mathrm{O}, 680,000 \mathrm{IU} / \mathrm{kg}$ of Vitamin $\mathrm{A}$, $160,000 \mathrm{IU} / \mathrm{kg}$ of Vitamin D, and 2,000 IU/kg of Vitamin E.

${ }^{4} \mathrm{NDSC}=$ Neutral detergent soluble carbohydrate

${ }^{5} \mathrm{NEI}$ was calculated based on NRC [4] 
(Table 2). Cows were housed in tie-stalls and fed ad libitum twice daily at 0900 and $2100 \mathrm{~h}$ with TMR, allowing for at least $10 \%$ residual (as-fed basis). Water and mineralized salt stone were available for cows during the experiment.

\section{Particle length and effectiveness fiber}

Feed particle size and distribution were determined by dry sieving in four replicates using two sets of a Penn State particle separator $[10,11]$. The NDF content of all materials retained on each sieve of the Penn State particle separator were measured [12]. Using three systems, the physical effective factor (pef) of the TMRs was determined. According to Mertens [13], Lammers et al. [10] and Kononoff [11], the pef was determined based on the proportion of DM retained on the 1.18-m sieve (pef $_{\mathbf{m}}$ ), on two 19- and 8-mm sieves $\left(\right.$ pef $_{>8}$ ), and three $19-, 8^{-}$, and $1.18-\mathrm{mm}$ sieves $\left(\right.$ pef $\left._{>\mathbf{1 . 1 8}}\right)$, respectively. The peNDF $_{m}$, peNDF $_{>8}$, and peNDF $>1.18$ were calculated by multiplying the NDF content of each portion on each sieve with the pef $_{\mathrm{m}}, \mathrm{pef}_{>8}$, and pef $_{>1.18}$, respectively (Table 2).

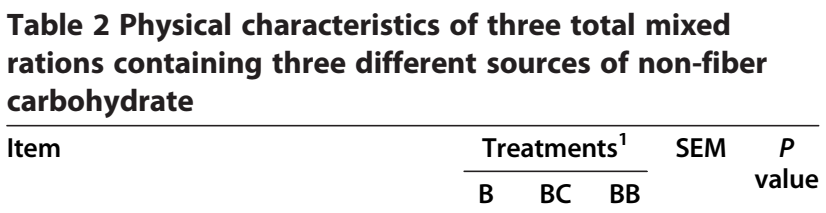

Particle size distribution (material retain on each sieve, \% of DM)

\begin{tabular}{|c|c|c|c|c|c|}
\hline $19 \mathrm{~mm}$ & 9.7 & 10.1 & 9.8 & 0.732 & 0.213 \\
\hline $8 \mathrm{~mm}$ & 22.2 & 22.1 & 20.4 & 0.912 & 0.133 \\
\hline $1.18 \mathrm{~mm}$ & 34.4 & 34.2 & 36.9 & 1.648 & 0.422 \\
\hline Pan & 33.7 & 33.6 & 32.9 & 0.641 & 0.455 \\
\hline Geometric mean, mm & 3.85 & 3.92 & 3.80 & 0.692 & 0.08 \\
\hline Standard deviation of geometric mean & 1.20 & 1.24 & 1.34 & 0.106 & 0.093 \\
\hline \multicolumn{6}{|l|}{ Physical effective factor } \\
\hline pef $_{m}^{2}$ & 66.2 & 66.3 & 66.9 & 0.509 & 0.101 \\
\hline pef $_{>} 8^{3}$ & 34.4 & 34.6 & 31.3 & 0.322 & 0.288 \\
\hline pef $_{>1.18^{4}}$ & 66.3 & 66.4 & 67.1 & 0.694 & 0.08 \\
\hline \multicolumn{6}{|l|}{ Physical effective NDF, \% of DM } \\
\hline peNDF $_{m}$ & 24 & 24 & 26 & 1.13 & 0.06 \\
\hline$e N D F>8$ & 12 & 13 & 12 & 1.03 & 0.0 \\
\hline eNDF $>1.18$ & 24 & 24 & 26 & 1.14 & \\
\hline
\end{tabular}

${ }^{1}$ Treatments were diets containing barley + basal diet (B), barley and corn + basal diet (BC), and barley and beet pulp + basal diet (BB).

${ }^{2}$ pef $_{m}=$ physically effective factor, based on DM retained on sieve

$1.18 \mathrm{~mm}$ [13].

${ }^{3}$ pef $_{>8}=$ physically effective factor, determined as the proportion of DM retained on sieves of the original version of Penn State particle separator [10] ${ }^{4}$ pef $_{>1.18}=$ physically effective factor, determined as the proportion of DM retained on sieves of the new version of Penn State particle separator [11]. ${ }^{5}$ The peNDF was calculated by multiplying NDF content of each portion on each sieve on each pef [13].
Body weight, intake, and apparent total-tract nutrient digestibility

The BW of cows was determined each wk. The DMI of the cows was measured daily (Table 3). Daily samples of TMRs, residuals and. total feces were collected daily for $5 \mathrm{~d}$ of each period at $0700 \mathrm{~h}$ on d 14 to $0700 \mathrm{~h}$ on $\mathrm{d} 20$, weighed, and d 5 samples were composited and subsampled. The samples were dried at $55^{\circ} \mathrm{C}$ for $48 \mathrm{~h}$ and ground using a Wiley mill (1-mm screen), analyzed for $\mathrm{DM}$, Kjeldahl N, ether extract, OM, ash at $605^{\circ} \mathrm{C}$ for $3 \mathrm{~h}$ [14], NDF, and ADF [12; with $\alpha$-amylase being added for concentrates during NDF extraction; sodium sulfite was not added]. Neutral detergent fiber was expressed without residual ash. Non-fibrous carbohydrate was calculated using the following equation: $100-\% \mathrm{CP}+\%$

Table 3 Body weight, intake, and digestibility of nutrients of three total mixed rations containing three different sources of non-fiber carbohydrates

\begin{tabular}{|c|c|c|c|c|c|}
\hline \multirow[t]{2}{*}{ Item } & \multicolumn{3}{|c|}{ Treatments $^{1}$} & \multirow[t]{2}{*}{ SEM } & \multirow{2}{*}{$\begin{array}{c}P \\
\text { value }\end{array}$} \\
\hline & B & $\mathrm{BC}$ & BB & & \\
\hline BW, kg & 600.63 & 591.84 & 583.25 & 11.212 & 0.140 \\
\hline \multicolumn{6}{|l|}{ Intake, kg/d } \\
\hline DM & $21.14^{b}$ & $21.02^{b}$ & $22.32^{a}$ & 0.530 & 0.004 \\
\hline NDF & $7.65^{b}$ & $7.76^{b}$ & $8.57^{a}$ & 0.021 & 0.001 \\
\hline peNDF $_{m}^{2}$ & $5.10^{b}$ & $5.14^{b}$ & $5.74^{\mathrm{a}}$ & 0.034 & 0.025 \\
\hline peNDF $_{>} 8^{3}$ & 2.63 & 2.68 & 2.68 & 0.231 & 0.075 \\
\hline peNDF $>1.18^{4}$ & $5.07^{b}$ & $5.15^{b}$ & $5.75^{a}$ & 0.023 & 0.024 \\
\hline$C P$ & 3.42 & 3.34 & 3.55 & 0.456 & 0.133 \\
\hline NFC & 8.22 & 8.18 & 8.46 & 0.345 & 0.309 \\
\hline Starch & $4.69^{a}$ & $4.25^{\mathrm{a}}$ & $3.24^{b}$ & 0.431 & 0.002 \\
\hline Sugar & 0.66 & 0.59 & 0.73 & 0.084 & 0.064 \\
\hline $\operatorname{NDSC}^{5}$ & $2.88^{c}$ & $3.34^{b}$ & $4.49^{\mathrm{a}}$ & 0.104 & 0.001 \\
\hline $\mathrm{EE}$ & 0.49 & 0.50 & 0.54 & 0.121 & 0.087 \\
\hline $\mathrm{OM}$ & 19.79 & 19.78 & 20.96 & 0.961 & 0.342 \\
\hline \multicolumn{6}{|l|}{ Digestibility, \% } \\
\hline DM & $64.58^{b}$ & $65.01^{b}$ & $66.91^{a}$ & 0.824 & 0.004 \\
\hline NDF & $61.58^{b}$ & $62.38^{b}$ & $68.82^{a}$ & 1.028 & 0.004 \\
\hline ADF & 51.67 & 52.21 & 52.33 & 0.769 & 0.100 \\
\hline$C P$ & 77.33 & 77.42 & 76.89 & 0.571 & 0.532 \\
\hline NFC & $83.36^{a}$ & $80.37^{b}$ & $80.90^{b}$ & 1.424 & 0.032 \\
\hline $\mathrm{EE}$ & $62.44^{b}$ & $66.52^{a b}$ & $67.33^{a}$ & 0.277 & 0.024 \\
\hline OM & 64.68 & 64.61 & 63.53 & 1.143 & 0.200 \\
\hline
\end{tabular}

a, b, cMeans within a row with different subscripts differ $(P<0.05)$.

${ }^{1}$ Treatments were diets containing barley + basal diet $(B)$, barley and corn + basal diet $(B C)$, and barley and beet pulp + basal diet (BB).

${ }^{2}$ peNDF $_{m}=$ physically effective NDF based on DM retained on sieve

$1.18 \mathrm{~mm}$ [13].

${ }^{3}$ peNDF $_{>8}=$ physically effective NDF, determined as the proportion of DM retained on sieves of the original version of Penn State particle separator [10] ${ }^{4}$ peNDF $_{>1.18}=$ physically effective NDF determined as the proportion of DM retained on sieves of the new version of Penn State particle separator [11]. ${ }^{5} \mathrm{NDSC}=$ Neutral detergent soluble carbohydrate. 
$\mathrm{NDF}+\%$ ash $+\%$ EE [4]. The TMR composites were analyzed for soluble sugars using sucrose as the standard and for starch [5]. The proportion of NDSC was computed as NFC (\%) using the following equation: [(Sugar (\%) + Starch (\%)] [5]. Using the chemical components of TMRs and feces, the intake and digestibility of nutrients were calculated. Intake $\left(\mathrm{kg} / \mathrm{d}\right.$ and\% of DMI) of peNDF ${ }_{\mathrm{m}}$, peNDF, ${ }_{>8}$ and peNDF $>1.18$ were calculated for each treatment (Table 3).

\section{Rumen fermentation and kinetics}

On d 21 of each period, ruminal fluid samples $(50 \mathrm{~mL})$ from the ventral sac were collected $3 \mathrm{~h}$ after the morning feeding using the rumenocentesis technique. Ruminal $\mathrm{pH}$ was measured immediately after ruminal fluid collection using a pH meter (model 632, Metrohm, Herisau, Switzerland), and samples were frozen at $-20^{\circ} \mathrm{C}$. The concentration of ammonia nitrogen $\left(\mathrm{NH}_{3}-\mathrm{N}\right)$ was measured using a Kjeltec Auto Analyzer (Model 1030, Tecator Co. Sweden). Ruminal fluids were acidified by mixing with $2.5 \mathrm{~mL}$ of $6 \mathrm{~mol} / \mathrm{L} \mathrm{HCl}$ and then frozen for further analysis of VFA and $\mathrm{NH}_{3}-\mathrm{N}$. Ruminal fluid was centrifuged at $25,000 \times g$ for 20 min before measurement of VFA by gas chromatography (4\% carbomax $80 / 120$ BDA column, Supelco Inc., Bellefonte, PA; Autosystem XL gas chromatograph, Perkin Elmer Inc., Norwalk, CT) [15].

Digestive kinetics were measured using $\mathrm{Cr}$-mordanted NDF alfalfa that was prepared by repeatedly soaking a mixture of alfalfa hay in dilute neutral detergent and rinsing until the NDF content of the material exceeded $80 \%$. The fiber was then dried at $55^{\circ} \mathrm{C}$. Chromium $(\mathrm{Cr})-$ mordanted alfalfa NDF was prepared as previously described by Uden et al. [16], as the single-dose marker for solid passage rate measurement. Cr-mordanted fiber was prepared by mordanting alfalfa NDF ground through a 5-mm screen using a Wiley mill. Each cow was orally fed with a mix of $2 \mathrm{~kg}$ of concentrate and $250 \mathrm{~g}$ of marker before morning feeding on the $15^{\text {th }} \mathrm{d}$ of each period. Fecal grab samples were collected at 0, 6, 10, 12, $14,18,22,26,30,36,42,48,54,60,72,84,96,120$, and $144 \mathrm{~h}$ after dosing from the rectum to determine the passage rate, ruminal, and total mean retention time, and time delay (transit time) of the marker. Samples were dry-ashed, and fecal $\mathrm{Cr}$ concentrations were determined by direct current plasma emission spectroscopy [14]. Fecal Cr excretion curves were fitted to the double compartment model, as represented by the following two exponential constants and a time delay [17]:

$$
\begin{aligned}
\mathrm{Y} & =\mathrm{Ae}_{1}^{\mathrm{k}(\mathrm{t}-\mathrm{TT})}-\mathrm{Ae}_{2}^{-\mathrm{k}}(\mathrm{t}-\mathrm{TT}), \mathrm{k}_{1}=\mathrm{k}_{2} \text { for } \mathrm{t}^{3} \mathrm{~T} ; \mathrm{Y}=0 \text { for } \mathrm{t} \\
& =\mathrm{TT} ;
\end{aligned}
$$

in which $\mathrm{Y}=$ marker concentration $(\mathrm{ppm}) ; \mathrm{A}=$ scale parameter; $\mathrm{k}_{1}=$ ruminal passage rate $(\% / \mathrm{h}) ; \mathrm{k}_{2}=$ lower digestive tract passage rate $(\% / \mathrm{h}) ; \mathrm{t}=$ sampling time post dosing (h); and $\mathrm{TT}=$ transit time or time delay of marker. The total mean retention time was calculated as the sum of ruminal mean retention time $\left(1 / \mathrm{k}_{1}\right)$, and for the lower digestive tract, mean retention time $\left(1 / \mathrm{k}_{2}\right)$ plus the transit time. Parameters were estimated by NLIN regression using the PROC NLIN (iterative Marquardt method) of $\mathrm{SAS}^{\oplus}$ [18]. The estimated parameters were analyzed according to a previously described experimental design.

\section{Eating, ruminating, and chewing times}

Eating and ruminating activities were monitored visually for all cows in each treatment over a 24-h period for $2 \mathrm{~d}$ and at d 22 to 23 of each period. Eating and ruminating activities were noted at 5-min intervals and each activity was assumed to persist for the entire interval. A period of rumination was defined as at least $5 \mathrm{~min}$ of ruminating activity, followed by at least 5 min without ruminating activity. Total time spent on chewing was calculated as the total time spent eating and ruminating [8].

\section{Milk production}

Milk yield was recorded daily during the course of the experiment. On d 18 to 23 of each period, milk samples were collected each morning and evening. Approximately $100 \mathrm{~mL}$ of each milk sample were composited and analyzed for total protein, fat, and lactose [14].

\section{Statistical analysis}

The data on particle size were analyzed as a completely randomized design for the effects of the diets and the two methods of particle size measurement using the REML variance component and PROC MIXED of SAS [18]. Mean separation was determined using the PDIFF procedure and significance was declared at $P<0.05$. The geometric mean and its standard deviation were calculated using ASAE S424.1 [7].

Using PROC MIXED of SAS ${ }^{\oplus}$ [18], the experimental data were analyzed in a $3 \times 3$ replicated Latin square design using following model:

$$
\mathrm{Y}_{\mathrm{ijkl}}=\mu+\mathrm{T}_{\mathrm{i}}+\mathrm{S}_{\mathrm{j}}+\operatorname{Cow}_{\mathrm{k}(\mathrm{j})}+\operatorname{period}+\mathrm{e}_{\mathrm{ijkl}}
$$

in which $Y_{i j k l}$ is the dependent variable; $\mu$ is overall mean; $T_{i}$ is fixed effect of the treatments $(i=1,2$, and 3 for diets containing $B, B C$, and $B B$ ); $S_{j}$, random effect of square $(j=1,2$, and 3$)$; $\operatorname{Cow}_{k(j)}$, effect of cow within square; period $_{1}$ within square, and $\mathrm{e}_{\mathrm{ijkl}}$ is residual error. Means were separated using Duncan's multiple range tests, with an alpha level of 0.05 . 


\section{Results}

Nutrient composition, particle size distribution, and physical effectiveness of different treatments

Except for starch $(P=0.001)$ and NDSC $(P=0.001)$ content, the three TMRs showed similar chemical compositions and physical characteristics (Tables 1 and 2). Concentrations of starch were similar for treatments B and $\mathrm{BC}$ and both were greater than that observed with treatment $\mathrm{BB}(22.2,20.2$, and $15.9 \%$, respectively). In addition, the concentration of NDSC increased with partial replacement of barley by corn and to a greater extent by partial replacement with $\mathrm{BP}(13.6,15.9$, and $20.1 \%$ for treatments $\mathrm{B}, \mathrm{BC}$, and $\mathrm{BB}$, respectively). Distribution of particles, expressed as the percentage of total mass, retained on the $19,8,1.18-\mathrm{mm}$ sieves for the three TMRs were also similar and averaged 9.7, 10.1, and 9.8; 22.2 , 22.1, and $20.4 ; 34.4,34.2$, and $36.9 \%$, respectively. The values of pef $_{\mathrm{m}}$, pef $_{>8}$, and pef ${ }_{>1.18}$ of the treatments were different among the systems. However, regardless of the methods and evaluation system, as well as the geometric mean and its standard deviation, their values were similar within each system. The peNDF values (\% of DM) were similar in all treatments (Table 2).

\section{Intakes and apparent total-tract nutrient digestibility}

Dry matter intake $(P=0.004)$, as well as NDF $(P=0.001)$, $\operatorname{peNDF}_{\mathrm{m}}(P=0.025)$, and $\operatorname{peNDF}_{>1.18}(P=0.024)$ intake were significantly different, although the intake of $\mathrm{CP}, \mathrm{NFC}$, $\mathrm{EE}$, and ash were similar among treatments. Replacing barley with BP increased DMI, but DMI in treatments B and $\mathrm{BC}$ were similar (Table 3). The nature of NFC affected DMI, as well as the production and composition of milk. Positive intake responses to feeding on BP were observed. Cows in the treatment $\mathrm{BB}$ group consumed more NDF, peNDF $_{m}$, and peNDF $>1.18$ compared with those in treatments $\mathrm{B}$ and $\mathrm{BC}$. The intake of starch $(P=0.002)$, sugars, and NDSC $(P=0.001)$ varied among the different NFC treatments. Cows fed on treatments $\mathrm{B}$ and $\mathrm{BC}$ showed a greater intake of starch compared with treatment BB. Cows assigned to the B diet showed the smallest sugar and NDSC intakes. NDF intake did not vary among treatments. However, there were some unexpected differences in the total NFC intake, ash, and CP. Digestibility of DM $(P=0.004)$, $\mathrm{NDF}(P=0.004), \mathrm{NFC}(P=0.032)$, and EE $(P=0.03)$ varied among treatments, although digestibility of $\mathrm{ADF}, \mathrm{CP}$, and OM remained the same (Table 3). The highest DM, NDF, and EE and significantly lower NFC digestibility were observed in treatment BB.

\section{Rumen fermentation and kinetics}

Lower $\mathrm{pH}$ levels were observed in cows that received treatments $\mathrm{B}$ and $\mathrm{BC}$ compared with those in treatment BB $(P=0.003)$. In addition, the $\mathrm{NH}_{3}-\mathrm{N}$ concentration varied among treatments $(P=0.035)$. The $\mathrm{NH}_{3}-\mathrm{N}$ concentrations were significantly lower in treatments $\mathrm{B}$ and $\mathrm{BC}$ than in treatment $\mathrm{BB}$. The total VFA concentration in treatment $\mathrm{BC}$ was similar to those observed in treatments $\mathrm{B}$ and $\mathrm{BB}$. Acetate concentration levels were also significantly different $(P<0.001)$ among treatments. The lowest values of acetate and acetate: propionate ratio was observed in treatment $B$, whereas the highest were observed in treatment BB. The butyrate concentration remained the same among treatments. The lowest values for propionate, isobutytate, valerate, and isovalerate were observed in treatment $\mathrm{BB}$, whereas the highest were in treatment $B$.

The ruminal particulate passage rate was highest and lowest in treatment $\mathrm{BC}$ and $\mathrm{BB}$, respectively. The ruminal and total mean retention time were higher in treatments $\mathrm{BB}$ than in treatments $\mathrm{B}$ and $\mathrm{BC}$. Contrary to the passage rate, treatments $\mathrm{BB}$ and $\mathrm{BC}$ showed the highest and lowest ruminal mean retention times, respectively. However, total mean retention time in treatment $\mathrm{BB}$ was higher than in treatments $\mathrm{B}$ and $\mathrm{BC}$ (Table 4). The time delay of the marker was significantly lower in treatment $\mathrm{B}$ than in BC (Table 4).

\section{Eating, ruminating, and chewing times}

No differences in eating time were observed among treatments, although rumination time $(P \leq 0.001)$ and total chewing activity $(P<0.001)$ varied (Table 5$)$. Rumination time and total chewing activity were lower and higher in $\mathrm{BC}$ compared with that observed in $\mathrm{B}$ and $\mathrm{BB}$. Treatment BB showed the highest rumination time and total chewing activity. Eating time ( $\mathrm{min} / \mathrm{kg}$ ) per NDF intake, peNDF$_{\mathrm{m}}$, and peNDF $_{>8}$ were higher in treatment $\mathrm{B}$ compared with treatments $\mathrm{BC}$ and $\mathrm{BB}$. However, no significant differences with regard to eating time per NDF intake, peNDF $_{\mathrm{m}}$, and $\mathrm{peNDF}_{>8}$ were observed among treatments $\mathrm{B}$ and $\mathrm{BB}$. Rumination time $(\mathrm{min} / \mathrm{kg})$ per DMI, NDF intake, peNDF $F_{m}, \operatorname{peNDF}_{>8}, \operatorname{peNDF}_{>1.18}$, and NFC were higher in treatments $\mathrm{BB}$ and $\mathrm{BB}$ compared with treatment $\mathrm{BC}$. However, no significant differences on rumination time per DMI, NDF intake, peNDF ${ }_{\mathrm{m}}$, peNDF $_{>8}$, peNDF $_{>1.18}$, and NFC were observed among treatments $\mathrm{BB}$ and $\mathrm{BB}$. In addition, total chewing activity $(\mathrm{min} / \mathrm{kg})$ per DMI, NDF intake, $\operatorname{peNDF}_{\mathrm{m}}, \operatorname{peNDF}_{>8}$, peNDF $_{>1.18}$, and NFC were higher in treatment BB compared with treatments $\mathrm{BC}$ and $\mathrm{BB}$. However, no differences on total chewing activity per $\operatorname{peNDF}_{\mathrm{m}}, \operatorname{peNDF}_{>8}$, peNDF $_{>1.18}$ were observed between treatments $\mathrm{BC}$ and $\mathrm{BB}$, and the total chewing activity per DMI, NDF and NFC intake was lower in treatment BC compared with treatment $\mathrm{BB}$. The eating time, rumination time, and total chewing activity per intake starch was higher in treatment $\mathrm{BB}$ than in treatments $\mathrm{B}$ and $\mathrm{BC}$, whereas that of treatments $\mathrm{B}$ and $\mathrm{BC}$ were similar. Also, the eating time, rumination time, and total chewing activity per 
Table 4 Ruminal metabolites and kinetic of digestion of three total mixed rations containing three different sources of non-fiber carbohydrate

\begin{tabular}{|c|c|c|c|c|c|}
\hline \multirow[t]{2}{*}{ Item } & \multicolumn{3}{|c|}{ Treatments $^{1}$} & \multirow[t]{2}{*}{ SEM } & \multirow[t]{2}{*}{$P$ value } \\
\hline & B & BC & BB & & \\
\hline $\mathrm{pH}$ & $6.62^{c}$ & $6.73^{b}$ & $6.83^{\mathrm{a}}$ & 0.002 & 0.003 \\
\hline $\mathrm{NH}_{3}-\mathrm{N}^{2}, \mathrm{mg} / \mathrm{dL}$ & $6.76^{\mathrm{b}}$ & $6.68^{b}$ & $7.71^{\mathrm{a}}$ & 0.111 & 0.035 \\
\hline \multicolumn{6}{|l|}{ VFA concentration } \\
\hline Total, mmol/L & $125.44^{\mathrm{a}}$ & $121.21^{\mathrm{b}}$ & $125.01^{\mathrm{a}}$ & 0.650 & $<0.001$ \\
\hline Acetate, $\mathrm{mol} / 100 \mathrm{~mol}$ & $58.21^{c}$ & $60.21^{b}$ & $63.05^{\mathrm{a}}$ & 0.435 & $<0.001$ \\
\hline Propionate, $\mathrm{mol} / 100 \mathrm{~mol}$ & $26.75^{\mathrm{a}}$ & $25.45^{b}$ & $23.04^{c}$ & 0.121 & $<0.001$ \\
\hline Butyrate, mol/100 mol & 6.48 & 6.33 & 6.28 & 0.104 & 0.075 \\
\hline Isobutytate, mol/100 mol & $2.39^{a}$ & $2.29^{\mathrm{a}}$ & $2.11^{\mathrm{b}}$ & 0.093 & 0.023 \\
\hline Valerate, mol/100 mol & $3.47^{\mathrm{a}}$ & $3.35^{\mathrm{ab}}$ & $3.25^{\mathrm{b}}$ & 0.096 & $<0.001$ \\
\hline Isovalerate, mol/100 mol & $2.49^{\mathrm{a}}$ & $2.37^{\mathrm{ab}}$ & $2.27^{\mathrm{b}}$ & 0.073 & 0.014 \\
\hline Acetate: propionate & $2.16^{c}$ & $2.37^{\mathrm{b}}$ & $2.75^{\mathrm{a}}$ & 0.053 & $<0.001$ \\
\hline Ruminal passage rate, $\% / \mathrm{h}$ & $4.36^{\mathrm{b}}$ & $5.46^{\mathrm{a}}$ & $4.06^{\mathrm{c}}$ & 0.097 & 0.012 \\
\hline Ruminal mean retention time, $\mathrm{h}$ & $23.48^{\mathrm{b}}$ & $18.32^{c}$ & $24.63^{\mathrm{a}}$ & 0.871 & 0.002 \\
\hline Total mean retention time, $\mathrm{h}$ & $54.36^{\mathrm{b}}$ & $52.64^{b}$ & $61.35^{\mathrm{a}}$ & 1.214 & 0.003 \\
\hline Time delay, $\mathrm{h}$ & $9.25^{b}$ & $10.24^{\mathrm{a}}$ & $9.86^{\mathrm{ab}}$ & 0.444 & 0.021 \\
\hline
\end{tabular}

a, b, c Means within a row with different subscripts differ $(P<0.05)$.

${ }^{1}$ Treatments were diets containing barley + basal diet (B), barley and corn + basal diet (BC), and barley and beet pulp + basal diet (BB).

${ }^{2} \mathrm{NH}_{3}-\mathrm{N}=$ ammonia nitrogen concentration.

intake NDSC was lower in treatment BB than in treatments $\mathrm{B}$ and $\mathrm{BC}$, and was significantly lower in treatment $\mathrm{BC}$ than in treatment B (Table 5).

\section{Milk production}

Although milk yield was not altered, replacing barley with corn and BP in the diet resulted in an increase in milk fat [yield $(P=0.013)$ ] and percentage $(P<0.001)$ and a decrease in milk protein (yield $(P=0.021)$ and percentage $[(P=0.001)$; Table 6$)]$, respectively.

\section{Discussion}

\section{Nutrient composition, particle size distribution, and} physical effectiveness

The pef $_{>8}$ values were lowest for TMRs, although the pef $_{m}$ and pef $_{>1.18}$ values were higher and very close. In contrast to the $\operatorname{peNDF}_{\mathrm{m}}$ and $\mathrm{peNDF}_{>1.18}$, the $\mathrm{peNDF}_{>8}$ values were similar among treatments. In this experiment, peNDF $_{m}$ and peNDF $>1.18$ were higher than $21 \%$ of the DM that Mertens [13] suggested to adequately stimulate chewing activity that was required to maintain an average ruminal $\mathrm{pH}$ of greater than 6.0. The peNDF content of experimental rations was adequate and the differences among treatments were attributable to the effects of NFC sources or its nature. The concentration of starch was similar in the $\mathrm{B}$ and $\mathrm{BC}$ treatments and higher than that observed in the $\mathrm{BB}$ treatment, but the NDSC significantly varied among treatments. These results thus confirm that intake of starch and NDSC varied with different NFC treatments. We hypothesized that the use different digestion products, which are the NFC complement of the diet, would alter feed intake, ruminal digestion kinetic, chewing activity, and the production and composition of milk.

\section{Intake and apparent total-tract nutrient digestibility}

The intake of $\mathrm{peNDF}_{\mathrm{m}}$ and $\mathrm{peNDF}_{>1.18}$ did not follow the same trend as the pef content of the diets, although this was similar to that of NDF; however, this increased in treatment BB. Treatment BB, which contained more NSDC, resulted in a significant increase in DMI. These results have been confirmed by several previous studies. Substitution of sugars and NDSC with starch has increased [19-22] or did not change [23] the intake in dairy cattle. Increases in dietary concentrations of NDSC at the expense of starch also increased [20,24], decreased $[22,25]$, or did not affect DMI [24]. Changes in the passage rate or fiber digestibility using various NFC sources may partial explain these changes [6]. A higher intake in treatment $\mathrm{BB}$ could have been expected based on the high NDSC and elevated starch content of barley and corn compared with treatments B and BC.

In this experiment, intake might have been regulated by the metabolism of propionate in the liver, and ruminal propionate production generally increases with a higher rate of starch fermentation. The amount of starch intake was 4.69, 4.25 , and $3.24 \mathrm{~kg} / \mathrm{d}$, and ruminal molar percent of propionate in total VFA was 26.75, 25.45, and $23.04 \mathrm{~mol} / 100 \mathrm{~mol}$ 
Table 5 Chewing activity of cows fed on three total mixed rations of three total mixed rations containing three different sources of non-fiber carbohydrates

\begin{tabular}{|c|c|c|c|c|c|}
\hline \multirow[t]{2}{*}{ Items } & \multicolumn{3}{|c|}{ Treatments $^{1}$} & \multirow[t]{2}{*}{ SEM } & \multirow[t]{2}{*}{$P$ value } \\
\hline & B & $\mathrm{BC}$ & BB & & \\
\hline Eating, $\min / \mathrm{d}$ & $257.8^{a}$ & $232.8^{\mathrm{b}}$ & $249.4^{\mathrm{ab}}$ & 10.272 & 0.045 \\
\hline Rumination, $\mathrm{min} / \mathrm{d}$ & $338.9^{\mathrm{b}}$ & $286.1^{c}$ & $356.1^{\mathrm{a}}$ & 7.430 & $<0.001$ \\
\hline Total chewing activity, $\mathrm{min} / \mathrm{d}$ & $596.7^{\mathrm{a}}$ & $518.9^{b}$ & $605.5^{\mathrm{a}}$ & 10.482 & $<0.001$ \\
\hline \multicolumn{6}{|c|}{ Chewing behaviour per different nutrients, $\mathrm{min} / \mathrm{kg}$} \\
\hline \multicolumn{6}{|l|}{ Eating } \\
\hline DMl & 12.19 & 11.08 & 11.174 & 0.552 & 0.200 \\
\hline NDF & $33.70^{\mathrm{a}}$ & $30.00^{b}$ & $29.10^{b}$ & 0.972 & 0.004 \\
\hline peNDF $_{m}^{2}$ & $50.55^{\mathrm{a}}$ & $45.29^{b}$ & $43.45^{\mathrm{b}}$ & 2.430 & 0.033 \\
\hline peNDF $>8^{3}$ & $97.93^{\mathrm{a}}$ & $86.75^{b}$ & $92.97^{\mathrm{ab}}$ & 4.431 & 0.002 \\
\hline peNDF $>1.18^{4}$ & 50.85 & 45.20 & 43.37 & 4.294 & 0.063 \\
\hline NFC & 31.36 & 28.46 & 29.42 & 1.154 & 0.088 \\
\hline Starch & $54.97^{b}$ & $54.78^{b}$ & $76.98^{\mathrm{a}}$ & 4.452 & $<0.001$ \\
\hline $\operatorname{NDSC}^{5}$ & $89.52^{\mathrm{a}}$ & $69.70^{b}$ & $55.55^{c}$ & 3.762 & $<0.001$ \\
\hline \multicolumn{6}{|l|}{ Rumination } \\
\hline DMl & $16.03^{\mathrm{a}}$ & $13.61^{b}$ & $15.95^{\mathrm{a}}$ & 0.350 & $<0.001$ \\
\hline NDF & $44.30^{\mathrm{a}}$ & $36.87^{b}$ & $41.55^{\mathrm{a}}$ & 1.561 & $<0.001$ \\
\hline peNDF $_{m}$ & $66.45^{\mathrm{a}}$ & $55.66^{b}$ & $62.04^{\mathrm{a}}$ & 1.902 & 0.003 \\
\hline peNDF $>8$ & $128.74^{\mathrm{a}}$ & $106.61^{b}$ & $132.74^{\mathrm{a}}$ & 5.242 & 0.009 \\
\hline peNDF > 1.18 & $66.84^{a}$ & $55.55^{b}$ & $61.93^{\mathrm{a}}$ & 1.615 & 0.002 \\
\hline NFC & $41.23^{\mathrm{a}}$ & $34.98^{b}$ & $42.09^{a}$ & 0.812 & $<0.001$ \\
\hline Starch & $72.26^{b}$ & $67.32^{b}$ & $109.91^{\mathrm{a}}$ & 6.692 & $<0.001$ \\
\hline NDSC & $117.67^{\mathrm{a}}$ & $85.66^{b}$ & $79.31^{c}$ & 3.833 & $<0.001$ \\
\hline \multicolumn{6}{|l|}{ Total chewing activity } \\
\hline DMl & $28.23^{\mathrm{a}}$ & $24.69^{c}$ & $26.13^{b}$ & 0.671 & $<0.001$ \\
\hline NDF & $78.00^{\mathrm{a}}$ & $66.87^{c}$ & $68.06^{b}$ & 2.031 & $<0.001$ \\
\hline peNDF $m$ & $117.00^{\mathrm{a}}$ & $100.95^{\mathrm{b}}$ & $101.61^{b}$ & 3.292 & $<0.001$ \\
\hline peNDF >8 & $216.41^{a}$ & $193.35^{b}$ & $225.71^{a}$ & 15.320 & $<0.001$ \\
\hline peNDF $>1.18$ & $117.69^{\mathrm{a}}$ & $100.76^{\mathrm{b}}$ & $101.43^{b}$ & 3.462 & 0.006 \\
\hline NFC & $72.59^{\mathrm{a}}$ & $63.43^{c}$ & $68.94^{b}$ & 1.752 & $<0.001$ \\
\hline Starch & $127.23^{b}$ & $122.09^{b}$ & $186.88^{\mathrm{a}}$ & 7.860 & $<0.001$ \\
\hline NDSC & $207.19^{\mathrm{a}}$ & $155.36^{b}$ & $134.86^{c}$ & 6.744 & $<0.001$ \\
\hline
\end{tabular}

a, b, cMeans within a row with different subscripts differ $(P<0.05)$.

${ }^{1}$ Treatments were diets containing barley + basal diet $(B)$, barley and corn + basal diet $(B C)$, and barley and beet pulp + basal diet (BB).

${ }^{2}$ peNDF $_{m}=$ physically effective NDF, based on DM retained on sieve $1.18 \mathrm{~mm}$ [13].

${ }^{3}$ peNDF $_{>8}=$ physically effective NDF, determined as the proportion of DM retained on sieves of the original version of Penn State particle separator [10].

${ }^{4}$ peNDF $_{>1.18}=$ physically effective NDF, determined as the proportion of DM retained on sieves of the new version of Penn State particle separator [11]

${ }^{5} \mathrm{NDSC}=$ Neutral detergent soluble carbohydrate.

in treatments $\mathrm{B}, \mathrm{BC}$, and $\mathrm{BB}$, respectively, showing that starch intake decreased with a higher rate of starch intake (Table 4). Therefore, it seems that propionate metabolism in the liver caused the reduction in DMI in treatments B and $\mathrm{BC}$ compared with $\mathrm{BB}$ because hepatic propionate oxidation probably decreased with the supplementation of $\mathrm{BP}$ [25]. In addition, ruminal $\mathrm{pH}$ might be implicated in the control of feed intake, particularly in satiety, because VFAs were more rapidly absorbed in the undissociated form at lower $\mathrm{pH}$. In addition, substituting a high-fiber byproduct such as BP for grain may have resulted in the reduction of energy content of the ration or the limitation of intake by the physical filling effects of the diet.

The NFC sources such as BP have a similar range of NDF content as forages, although its particle length was generally smaller. In several experiments, these sources 
Table 6 Milk production and composition of cows fed on three total mixed rations containing three different sources of non-fiber carbohydrates

\begin{tabular}{|c|c|c|c|c|c|}
\hline \multirow{2}{*}{ Item } & \multicolumn{3}{|c|}{ Treatments $^{1}$} & \multirow{2}{*}{ SEM } & \multirow{2}{*}{$\begin{array}{c}P \\
\text { value }\end{array}$} \\
\hline & B & $\mathrm{BC}$ & BB & & \\
\hline \multicolumn{6}{|c|}{ Yield of milk and milk components, $\mathrm{kg} / \mathrm{d}$} \\
\hline Milk & 25.11 & 25.50 & 25.83 & 0.653 & 0.062 \\
\hline $3.5 \%$ FCM & 21.69 & 22.43 & 22.69 & 0.645 & 0.070 \\
\hline Fat & $0.86^{\mathrm{b}}$ & $0.90^{\mathrm{a}}$ & $0.91^{\mathrm{a}}$ & 0.033 & 0.013 \\
\hline Protein & $0.81^{\mathrm{a}}$ & $0.80^{\mathrm{b}}$ & $0.80^{\mathrm{b}}$ & 0.025 & 0.021 \\
\hline Lactose & 1.17 & 1.20 & 1.16 & 0.020 & 0.062 \\
\hline Total solid & 3.47 & 3.42 & 3.57 & 0.060 & 0.076 \\
\hline \multicolumn{6}{|c|}{ Milk composition, \% } \\
\hline Fat & $3.43^{\mathrm{b}}$ & $3.55^{\mathrm{b}}$ & $3.63^{\mathrm{a}}$ & 0.087 & $<0.001$ \\
\hline Protein & $3.23^{\mathrm{a}}$ & $3.15^{\mathrm{b}}$ & $3.10^{\mathrm{b}}$ & 0.030 & 0.001 \\
\hline Lactose & 4.67 & 4.69 & 4.66 & 0.045 & 0.058 \\
\hline Total solid & 11.93 & 11.89 & 12.01 & 0.098 & 0.060 \\
\hline
\end{tabular}

a, bMeans within a row with different subscripts differ $(P<0.05)$.

${ }^{1}$ Treatments were diets containing barley + basal diet $(B)$, barley and corn + basal diet (BC), and barley and beet pulp + basal diet (BB).

were substituted with forage or grain in diets and then the DMI was measured $[3,5,6,22]$. When DMI is regulated by ruminal distension, its substitution with forage in diets results in an increase in DMI, whereas its substitution with grain decreases DMI $[2,4,13]$. However, nonforage fiber sources showed inconsistent effects on DMI when substituted with either forage or grain in the diets of lactating cows. In the current experiment, the physical characteristics of the diets were similar; therefore, it seems that these do not differ in their relative filling effects. In treatment BB, the DMI was not regulated by ruminal distension $[3,25]$. The greater concentration of propionate in the ruminal liquid in treatment $\mathrm{B}$ compared with treatments $\mathrm{BC}$ and $\mathrm{BB}$ suggests that stimulated propionate receptors in the ruminal region may have controlled satiety and DMI, because propionate is more hypophagic than acetate, resulting in a lower DMI in treatment $B$ versus treatments $B C$ and $B B[19,26]$.

Partially replacing barley with $\mathrm{BP}$ in the dairy cow diet resulted in an increase in total digestibility of DM, NDF, and EE, and a decrease in the digestibility of NFC. However, partially replacing barley with corn in the dairy cow diets showed minimal effects on total digestibility. Unfortunately, total digestibility of starch was not measured in this study. In the present study, decreased fiber digestibility in treatment $\mathrm{B}$ using barley was consistent with the reduction in rumination time, ruminal $\mathrm{pH}$, and acetate to propionate ratio. The consumption of diets rich in NDSC imparted positive effects on ruminal digestion. In addition, the results of this experiment might be influenced by differences in the digestible NDF of the treatment diet and not simply the source of NFC, as implied in the objectives of this study.

Differences in digestible NDF rations or starch, NDSC, and sugar content were associated with several parameters, especially acetate and propionate concentrations and their ratio in the rumen, as well as milk fat and protein content. These were significantly different among treatments $(P<0.001)$ and treatment $\mathrm{BB}$ showed the highest intake of potentially digestible fiber or NDSC. Previous studies have confirmed that animal intake response to supplemented starch- or pectin-rich feeds remained the same, although changes in digestibilities have been observed. Valk et al. [22] reported that cows fed on corn consumed more DM and produced more milk than cows fed on BP. However, DMI and digestibility of NDF were higher in cows fed on BP compared with those fed on corn meal.

The extent and rate of degradation is extremely variable among grains, byproducts, and different sources of NFC [6,27]. Variation in ruminal degradation of DM and OM across feeds has been reported to range from $29 \%$ to $90 \%$, and $29 \%$ to $67 \%$, respectively [27]. Total tract digestibility of corn ranges from $91.2 \%$ to $98.9 \%$, depending on the processing method and grain type, with ground corn averaging 93.5\% [28]. Ruminal degradation of starch in ground corn and ground barley ranged from $51 \%$ to $93 \%$, and $42 \%$ to $91 \%$, respectively [28]. In addition, ruminal degradation of DM and NDF in BP was $78 \%$ [29] and 94.1\% [30], respectively. The potentially digestible fraction leaves the rumen either by degradation or by passage to the lower tract. Furthermore, feed characteristics and ruminal fractional passage rates would most likely vary; these tend to be higher with fine, non-forage fiber sources due to differences in ruminal retention time, which may be influenced by ruminal consistency [6]. The inclusion of BP in treatment BB resulted in a decrease in particulate passage rates, an increase in ruminal and total mean retention time, and a positive effect on ruminal and total digestion.

\section{Rumen fermentation and kinetics}

Variables of ruminal $\mathrm{pH}$ such as the outflow rate of digesta from the reticulorumen or ruminal indicate that retention time influences total fiber degradation. Rapidly fermenting carbohydrates such as sugars, NDSC, and some starches have the potential to rapidly decrease ruminal $\mathrm{pH}$ by virtue of the sheer mass of organic acids produced in this digestive region within a relatively short period of time. The ruminal $\mathrm{pH}$ corresponded to a higher rate of degradation and fermentation of barley grain that produced the highest concentration of total VFA and propionate, lower acetate, and acetate: propionate ratio in treatment $\mathrm{B}$ compared with the other treatments (Table 4). 
Beet pulp, which is rich in pectin or NDSC, has been shown to yield relatively high amounts of acetic acid, thus resulting in an increase in the acetate to propionate ratio and less butyrate and lactate compared with other carbohydrate sources [31]. In addition, using twelve Friesian cows and sixteen heifers, Lees et al. [21] reported that in wk 9 and 16, the ruminal VFA proportions of cows fed on BP were higher for acetate and butyrate and lower for propionate compared with cows fed on corn. The molar proportion of acetate in the current study and in previous investigations was probably altered by the tendency of BP to increase fiber intake and digestion. In contrast, Van Vuuren et al. [32] did not detect any differences in ruminal fluid $\mathrm{pH}$ or VFA concentrations in either experiment involving cows fed on corn products or BP and soybean hulls.

Changing the dietary source of NFC or NDSC and starch content of diet rations of lactating dairy cows has been shown to alter the ruminal environment and fermentation products. The effects, although not always consistent, have been observed on the proportions of VFA, the concentration of rumen $\mathrm{NH}_{3}-\mathrm{N}$, and the extent of fiber digestion with feeding starch, sugars, or NDSCrich feeds [6]. The application of treatment $\mathrm{BC}$ resulted in a higher acidic $\mathrm{pH}$, lower total VFA and proportion of propionate, and increased acetate concentration and acetate:propionate ratio in the ruminal fluid. Replacing $\mathrm{BP}$ with barley resulted in a higher acidic $\mathrm{pH}$, increased acetate concentration in ruminal fluid, without any change in total VFA, and decreased proportion of propionate, valerate, isobutyrate, and isovalerate. Therefore, compared with barley, BP created more favorable conditions for microbial utilization of other carbohydrates in the rumen, at least in part due to the neutral $\mathrm{pH}$. Decreasing daily mean ruminal $\mathrm{pH}$, which was associated with an increase in ruminal outflow rate of digesta, resulted in a decrease in ruminal NDF digestibility and total tract digestibility $[2,8,9,33$ ]. Zebeli et al. [9] showed a decrease in total tract NDF digestibility by increasing the outflow rate of particulate digesta, which was associated with a decrease in ruminal mat consistency. It might be possible that a low digesta passage rate and high consistency in the ruminal mat due to inclusion of $\mathrm{BP}$ in the treatment $\mathrm{BB}$ was associated with a higher water holding capacity, greater entrapment of small particles, decreased outflow rate of solid digesta, and increased ruminal NDF digestibility in dairy cows.

The ruminal particulate passage rate was highest and lowest in treatments $\mathrm{BC}$ and $\mathrm{BB}$, respectively. Because corn has a higher specific gravity than barley and BB, inclusion of corn in the diet resulted in an increase in ruminal passage rate and a decrease in rumen mean retention time (Table 4), and consequently, it decreased rumination time and total chewing activity. In contrast, the higher total chewing activity in treatment $\mathrm{BB}$ might have resulted from the lower $\mathrm{pH}$ that was attributable to a high degradability of barley, which may have decreased the rate and extent of NDF digestion. In treatment BB, the $\mathrm{BP}$ did not result in a reduction in ruminal $\mathrm{pH}$ despite its high rate of NDF digestion because of the production of a higher concentration of acetate and lower propionate. However, it has a low functional specific gravity and a large particle size [34], which could decrease its passage rate and increase its ruminal mean retention time and consequently, rumination and total chewing activity.

Two characteristics that affect the passage of digesta are density and particle size. In addition, there is a clear negative relationship between particle density and ruminal mean retention time. Particles with a specific gravity of lower than the critical size $(1.18 \mathrm{~mm})$ quickly pass out of the reticulorumen [8]. The specific gravity for BP was 1.152 , whereas that of barley and corn grain were higher than 1.237 [34]. Therefore, inclusion of BP in treatment $\mathrm{BB}$ decreased particulate passage rates and increased ruminal and total mean retention time. Particles with a density range of 1.2 to 1.5 showed the highest rate of passage in cattle and sheep $[3,8,9]$. Grain and its byproducts (except for BP and soy hulls] showed a higher rate of passage from the rumen than forages because of the higher functional specific gravity and a particle size much smaller than that associated with stimulation of rumination. Therefore, most grains would have a faster rate of passage from the rumen than forages and other byproducts.

In treatment $\mathrm{B}$, negative associative effects resulting from a lower $\mathrm{pH}$ due to a high degradability of barley would probably decrease the rate of digestion. Beet pulp did not reduce ruminal $\mathrm{pH}$ despite its high rate of NDF digestion [3]; however, it has a low functional specific gravity and a large particle size [34], which could decrease its passage rate and increase its ruminal mean retention time. Therefore, BP should have a very high ruminal digestibility [29], potentially supporting levels of ruminal microbial protein synthesis and milk production, similar to that observed in corn [31]. However, generalization of these results under different feeding conditions would be an oversimplification because different dietary treatments can interact with each other, thus affecting passage rate.

\section{Eating, ruminating, and chewing times}

Although the effect of forage particle size on chewing behavior has been substantially investigated, information on the effects of NFC, starch, or NDSC content of ration, especially when barley grain partially replaced with corn and BP, is limited. Despite the absence of differences in eating time, the rumination time and total 
chewing activity significantly varied among treatments. Prolonged total chewing time due to the increase in dietary peNDF resulted from an increase in ruminating time rather than an increase in eating time.

Treatment $\mathrm{BB}$ showed the highest rumination time and total chewing activity. Total daily chewing time varied from 8.6, 9.9, and $10.1 \mathrm{~h}$, with ruminating time at $5.6,4.8$, and $5.9 \mathrm{~h}$ in treatments $\mathrm{B}, \mathrm{BC}$, and $\mathrm{BB}$, respectively. These values were within limits previously reported for dairy cows $[9,13]$, although the mean chewing time per kg DM ingested was less than 30 min, contrary to the recommendations of Mertens [13], who proposed values equal to or exceeding $30 \mathrm{~min} / \mathrm{kg} \mathrm{DM}$ intake as suitable for limiting the risk of digestive disorders. Eating time per day and per kilogram of DMI increased with the supplementation of BP. As diet NDF intake increased with added BP in the current study, a decrease in time eating per kilogram of NDF was observed. However, no effect of BP substitution for corn on time eating per day or per kilogram of DMI was reported $[2,13]$. Tafaj et al. [2] and Zebeli et al. [9] have previously shown that the fiber content (NDF or forage NDF) and nonfiber carbohydrates in the diet affected daily chewing and rumination activities. Forage content remained the same across treatments; therefore, the nature of NFC or starch and NDSC content impacted the rate of feed intake, ruminal mean retention time, rumination time, and total chewing activity.

\section{Milk production}

Although milk yield was not altered, replacing corn and BP with barley in diets resulted in an increase in milk fat (yield and percentage), and a decrease in protein concentration (yield and percentage; Table 6). Dietary BP can increase [27], decrease [22], or support milk yield, which have also been observed in cows fed on corn or barley [22,35]. In addition, intake may be improved [21], decreased [22,35], or remain the same [27,35] using BP. Various dietary carbohydrates can result in changes in ruminal fermentation and generate VFAs patterns that influence the hormonal status of the animal and potentially affect milk production and composition.

The increase in fat secretion in treatments $\mathrm{BC}$ and $\mathrm{BB}$ has been shown to elevate both acetate and acetate: propionate ratio in the rumen. However, treatments $\mathrm{BC}$ and $\mathrm{BB}$ did not alter ruminal concentrations of either the total VFA or butyrate. Mansfield et al. [31] previously showed a higher milk fat concentration (3.82 vs. 3.64), whereas milk protein $(3.01 \%$ vs. $2.90 \%)$ and yield were lower in cows fed on the BP diet compared with the corn diet. The fat content of milk was enhanced in treatment $\mathrm{BB}$, which can be directly attributed to the increase in fiber intake and digestion in cows and the molar proportion of acetate in the rumen. Consistent with the current experiment, milk fat increased in cows fed on the BP diet as a replacement for grain $[22,31]$ due to the higher fiber intake and greater acetate concentrations in the rumen. It seems that the higher milk fat observed in treatment $\mathrm{BB}$ was due to the increase in intake of digestible NDF and NDSC, ruminal mean retention time, rumination time, total chewing activity, ruminal acetate concentration, and ruminal $\mathrm{pH}$.

A decrease in milk $\mathrm{CP}$ content and yield was observed when corn and BP were substituted with barley. This finding was confirmed by Mansfield et al. [31], but was in contrast to the findings of Valk et al. [22]. In contrast to the current experiment, a lower intake of $\mathrm{CP}$, lower $\mathrm{NH}_{3}-\mathrm{N}$ concentrations in the rumen, and lower $\mathrm{CP}$ degradability for cows fed on BP was observed, compared with that in cows fed on corn [20] or barley [33]. The consumption of carbohydrates such as NDSC that are more extensively fermented in the rumen may improve the utilization of the NPN through the stimulation of microbial protein synthesis. In contrast, when $\mathrm{NH}_{3}-\mathrm{N}$ concentrations in the rumen cannot meet microbial requirements, the fermentation of fiber is reduced and the animal responds with a lower intake and digestibility. Total VFA concentration in treatments $\mathrm{BC}$ and $\mathrm{BB}$ were observed to decrease. The lower total rumen VFA is an indicator of lower ruminal fermentation of fiber that limited milk protein yield. Huhtanen [27], Rooke et al. [36], and Chcster-Jones et al. [20] previously showed that BP supports VFA concentrations in the rumen similar to those for corn and barley grain, whereas VFA concentrations decreased in some situations [6]. In addition, NFC sources that were used in the current experiment varied in their DM rate and extent degradability, support of microbial yield, and supply of protein to the small intestine because microbial $\mathrm{CP}$ yield is influenced by carbohydrate and nitrogen sources, rate of carbohydrate fermentation, bacterial growth rate, ruminal dilution rate, and $\mathrm{pH}[22]$.

\section{Conclusion}

The results of this study indicate that changing dietary NFC or starch and NDSC that possess a different level of degradability may alter intake, ruminal mat consistency, chewing activity, ruminal environment, and retention time or passage rate, and lactation performance. However, studies on the optimal concentrations of NFC from different sources, in combination with other dietary components, are warranted to monitor the lactation performance of dairy cows.

\section{Competing interests}

The authors declare that they have no competing interests.

\section{Authors' contributions}

All authors have made substantial contributions to: the research design, analysis or interpretation of data, and in drafting the paper. Both authors read and approved the final manuscript. 
Received: 4 June 2013 Accepted: 28 December 2013

Published: 13 January 2014

\section{References}

1. Grant RJ: Interactions among forages and non-forage fiber sources. J Dairy Sci 1997, 80:1438-1446.

2. Tafaj M, Zebeli Q, Baes C, Steingass H, Drochner W: A meta-analysis examining effects of particle size of total mixed rations on intake, rumen digestion and milk production in high yielding dairy cows in early lactation. Anim Feed Sci Technol 2007, 138:137-161.

3. Varga AG: Soluble carbohydrates for lactating dairy cows, Proceeding of Tri-State Dairy Nutrition Conference. Columbus: The Ohio State University; 2003:59-73.

4. National Research Council (NRC): Nutrient Requirements of Dairy Cattle, 7th rev. Washington, DC: Natl. Acad. Sci; 2001.

5. Hall MB, Hoover WH, Jennings JP, Webster TKM: A method for partitioning neutral detergent-soluble carbohydrates. J Sci Food Agric 1999, 79:2079-2086.

6. Larson CC: The effects of non-fiber carbohydrate sources and protein degradability on performance of Holstein cows, Ph.D. Thesis. University of Florida: Department of Animal Sci; 2003.

7. American Society of Agricultural Engineers: Method of determining and expressing particle size of chopped forage (S424.1). 70th edition. St. Joseph, Ml: Am Society Agric Engineering; 2002:619-921.

8. Teimouri Yansari A, Primohammadi R: Effect of particle size of alfalfa hay and reconstitution with water on intake, digestion, and milk production in Holstein dairy cows. Animal 2009, 3:218-227.

9. Zebeli Q, Dijkstra J, Tafaj M, Steingass H, Ametaj BN, Drochner W: Modeling the adequacy of dietary fiber in dairy cows based on the responses of ruminal $\mathrm{pH}$ and milk fat production to composition of the diet. J Dairy Sci 2008, 91:2046-2066.

10. Lammers BP, Buckmaster DR, Heinrichs AJ: A simple method for the analysis of particle sizes of forages and total mixed rations. J Dairy SCi 1996, 79:922-928.

11. Kononoff PJ: The effect of ration particle size on dairy cows in early lactation Ph.D. Thesis. The Pennsylvania State Univ: Department of Animal Sci; 2002.

12. Van Soest PJ, Robertson JB, Lewis BA: Methods for dietary fiber, neutra detergent fiber, and non-starch polysaccharide in relation to animal nutrition. J Dairy Sci 1991, 74:3583-3597.

13. Mertens DR: Creating a system for meeting the fiber requirements of dairy cows. J Dairy Sci 1997, 80:1463-1481.

14. Association of Official Analytical Chemists: Official Methods of Analysis, Volume 1. 17th edition. Arlington, VA: AOAC; 2002:1-75

15. Merchen NR, Firkins $J$, Berger $L L$ : Effect of intake and forage level on ruminal turn over rates, bacterial protein synthesis and duodenal amino acid flows in sheep. J Anim Sci 1986, 62:216-224.

16. Uden P, Colucci E, Van Soest PJ: Investigation of chromium, cerium, and cobalt as markers in digesta rate of passage studies. J Sci Food Agric 1980, 31:625-632

17. Grovum WL, Williams VJ: Rate of passage of digesta in sheep 4: Passage of markers through the alimentary tract and the biological relevance of rate-constants derived from changes in concentration of markers in feces. Br J Nutr 1973, 30:231-242.

18. User's Guide SAS: Statistics, version 8.2. Cary, NC: SAS Inst. Inc; 1998.

19. Broderick GA, Luchini ND, Radloff WJ, Varga GA, Ishler VA: Effect of replacing dietary starch with sucrose on milk production in lactating dairy cows. U.S: Dairy Forage Research Center 2000-2001 Research Report; 2002:116-118.

20. Chester-Jones H, Stern MD, Metwally HM, Linn JG, Ziegler DM: Effects of dietary protein-energy interrelationships on Holstein steer performance and ruminal bacterial fermentation in continuous culture. J Anim SC 1991, 69:4956-4966. 69.

21. Lees JA, Oldham ID, Haresign W, Gamsworthy PC: The effect of patterns of rumen fermentation on the response by dairy cows to dietary protein concentration. Br J Nutr 1990, 63:177-187.

22. Valk H, KleinPoelhuis HW, Wentink HJ: Effects of fibrous and starchy carbohydrates in concentrates as supplements in a herbage-based diet for high yielding dairy cows. Neth J Agric Sci 1990, 38:475-486.

23. Friggens NC, Emmans GC, Robertson S, Chamberlain DG, Whittemore CT, Oldham JD: The lactational responses of dairy cows to the amount of feed and to the source of carbohydrate energy. J Dairy Sci 1995, 78:1734-1744.
24. Leiva $\mathrm{E}, \mathrm{Hall} \mathrm{MB}$, Van Horn HH: Performance of dairy cattle fed citrus pulp or corn products as sources of neutral detergent-soluble carbohydrates. J Dairy Sci 2000, 83:2866-2875.

25. Allen MS: Effects of diet on short-term regulation of feed intake by lactating dairy cattle. J Dairy Sci 2000, 83:1598-1624.

26. Broderick GA, Mertens DR, Simons R: Efficacy of carbohydrate sources for milk production by cows fed diets based on alfalfa silage. J Dairy Sci 2002, 8:1767-1776.

27. Huhtanen P: The effect of dietary inclusion of barley, unmolassed sugar beet pulp and molasses on milk production, digestibility and digesta passage in dairy cows given silage based diet. J Sci Food Agric 1987, 59:101-|111.

28. Huntington GB: Starch utilization by ruminants: from basics to the bunk. J Anim Sci 1997, 75:852-867.

29. Torrent J, Johnson DE, Kujawa MA: Co-product fiber digestibility: kinetic and in vivo assessment. J Anim Sci 1994, 72:790-795.

30. DePeters EJ, Fadel JG, Arosemena A: Digestion kinetics of neutral detergent fiber and chemical composition within some selected by-product feedstuffs. Anim Feed Sci Technol 1991, 67:127-140.

31. Mansfield HR, Stern MD, Otterby DE: Effects of beet pulp and animal by-products on milk yield and in vitro fermentation by rumen microorganisms. J Dairy Sci 1994, 77:205-216.

32. Van Vuuren AM, Van Der Koelen CJ, Vroons-De Bruin J: Ryegrass versus corn starch or beet pulp fiber diet effects of digestion and intestinal amino acids in dairy cows. J Dairy Sci 1993, 76:2692-2700.

33. Teimouri Yansari A, Valizadeh $R$, Naserian A, Christensen DA, Yu P, Eftekhari Shahroodi F: Effects of alfalfa particle size and specific gravity on chewing activity, digestibility, and performance of Holstein dairy cows. J Dairy Sci 2004, 87:3912-3924.

34. Bhatti SA, Firkins JL: Kinetics of hydration and functional specific gravity of fibrous feed by-products. J Anim Sci 1995, 73:1449-1458.

35. DeVisser H, Van der Togh PL, Tamminga S: Structural and nonstructural carbohydrates in concentrate supplements of silage-based dairy cow rations. 1. Feed intake and milk production. Neth J Agric Sci 1990, 38:487-497

36. Rooke JA, Rymer C, Maya FM, Armstrong DG: Effect of including barley or molassed sugar beet feed in grass silage diets on their digestion by cattle and sheep. J Sci Food Agric 1992, 48:475-489.

doi:10.1186/2049-1891-5-6

Cite this article as: Poorkasegaran and Yansari: Effects of different sources of carbohydrates on intake, digestibility, chewing, and performance of Holstein dairy cows. Journal of Animal Science and Biotechnology 2014 5:6.

\section{Submit your next manuscript to BioMed Central and take full advantage of:}

- Convenient online submission

- Thorough peer review

- No space constraints or color figure charges

- Immediate publication on acceptance

- Inclusion in PubMed, CAS, Scopus and Google Scholar

- Research which is freely available for redistribution 